\title{
VARIATION IN BIOFUEL POTENTIAL OF TWELVE Calophyllum inophyllum POPULATIONS IN INDONESIA
}

\author{
Budi Leksono $^{1 *}$, Rina Laksmi Hendrati ${ }^{1}$, Eritrina Windyarini ${ }^{1}$ and Trimaria Hasnah ${ }^{1}$
}

Received : 23 October 2013, Accepted : 16 July 2014

\begin{abstract}
The global energy crisis has raises demand for biofuel prices. It has driven the world to enhance environmentally-friendly renewable-energy (biofuel) production. Oil from the seeds of Calophyllum inophyllum (nyamplung) which can be harvested up to 50 years, is one of such potential biofuel source. Methods for biofuel production from nyamplung seeds have been developed at an industrial scale by cooperative in Cilacap (Java) and Energy Self-Sufficient Villages (Desa Mandiri Energi) in Banyuwangi, Purworejo, Kebumen, Ujung Kulon (Java) and Selayar (South Sulawesi). However, there is only a limited-information available on biofuel potential, in term of productivity and quality, from nyamplung populations. This paper reports the variations in biofuel potential among 12 populations in Indonesia ( 6 from Java, 6 outside Java). The oil was extracted using a combination of vertical hot press (VHP) and screw press expeller (SPE) methods, followed by degumming to make refined oil, and esterification-transesterification to turn it into biodiesel. The result show great variation of biofuel content among the population. Oil production percentage varies from $37-48.5 \%$ (VHP) and 50-58\% (SPE) crude oil, 36-48\% (VHP) and 40-53\% (SPE) refined oil, and 17$33 \%$ (SPE) for biodiesel. Seed resin content is responsible for most of the variation after degumming. DNA analysis shows genetic variation among populations ranges from intermediate within Java to high ouside Java and is intermediate within populations. Information about biofuel content and potential of populations and genetic variation between and within population are important factors for establishment of geneticallyimproved seed-sources for biofuel production from nyamplung.
\end{abstract}

Keywords: Biofuel, crude oil, genetic-variation, nyamplung (Calophyllum inophyllum)

\begin{abstract}
ABSTRAK
Krisis energi mendorong penduduk dunia untuk mengalihkan sumber energinya ke energi terbarukan (biofuel) yang lebih ramah lingkungan. Nyamplung (Calophyllum inophyllum) sebagai salah satu jenis tanaman hutan mempunyai potensi sebagai bahan baku biofuel dari bijinya dan dapat berproduksi sampai dengan umur 50 tahun. Secara teknis pemanfaatan biji nyamplung sebagai biofuel tidak menjadi masalah dan sudah mulai dikembangkan dalam skala industri oleh Koperasi Jarak Lestari di Cilacap (Jawa Tengah) dan melalui program Desa Mandiri Energi (DME) berbasis nyamplung di Banyuwangi (Jawa Timur), Purworejo dan Kebumen (Jawa Tengah), Ujung Kulon (Banten), dan Selayar (Sulawesi Selatan). Namun demikian, ketersediaan dan kualitas bahan baku dari biji nyamplung menjadi kendala utama karena belum tersedia informasi produktivitas minyak yang optimal. Tulisan ini menyajikan variasi potensi biofuel nyamplung dari 12 (dua belas) populasi nyamplung di Indonesia (6 populasi di Jawa dan 6 populasi di luar Jawa) untuk membangun sumber benih unggul nyamplung. Rendemen minyak dihasilkan dengan menggunakan kombinasi alat Vertical Hot Press (VHP) dan Screw Press Expeller (SPE) dilanjutkan dengan proses degumming untuk menghasilkan refined oil dan proses esterifikasi-transesterifikasi untuk menghasilkan biodiesel. Hasil penelitian menunjukkan terdapat variasi yang cukup tinggi diantara populasi nyamplung di Indonesia
\end{abstract}

${ }^{1}$ Center for Forest Biotechnology and Tree Improvement, Jl. Palagan Tentara Pelajar Km 15, Purwobinangun, Pakem, Sleman, Yogyakarta

*Corresponding author: boedyleksono@yahoo.com 
terhadap rendemen biofuel. Persentase rendemen minyak bervariasi antara 37-48,5\% dengan VHP dan 5058\% dengan SPE untuk crude oil, 36-48\% (VHP) dan 40-53\% (SPE) refined oil, dan 17-33\% (SPE) untuk biodiesel. Variasi tertinggi ditunjukkan pada rendemen biofuel setelah degumming karena biji nyamplung mengandung getah yang cukup tinggi. Analisa DNA menunjukkan variasi genetik antar populasi bervariasi dari sedang untuk populasi di Jawa sampai dengan tinggi untuk populasi di luar Jawa. Informasi rendemen biofuel dan potensi dari populasi nyamplung serta variasi genetik antar populasi dan didalam populasi menjadi faktor penting untuk pembangunan sumber benih unggul untuk produksi biofuel nyamplung.

Kata kunci: Biofuel, minyak mentah, nyamplung (Calophyllum inophyllum), variasi genetik

\section{INTRODUCTION}

Biofuel demand and prices are affected by the global energy crises. It has been the crucial reason for the world to urgently look for renewable-energy (biofuel) sources that are environmentally friendly. Biofuel is one of the many alternative forms of energy (Hayes et al., 2007). In this context, the Indonesian government through the national energy policy has set biofuel production target to contribute by $5 \%$ of the national energy needs in 2025 . The Ministry of Forestry was assigned to play an important role in providing biofuel raw materials and to give explicit licence for the use of unproductive forest lands for further biofuel development (ESDM, 2006).

In general, there is no crucial constraint in the technology of the biofuel process. However, more research on increasing its efficiency is required for making it feasible at operational scale. The main restraints are raw material availability, quality and strong competition from the food sector, in the context of food security. Currently, biofuel production is obtained primarily from food sources such as oil palm, coconut, cassava, corn, sorghum and other sources of carbohydrats. Non-edible biofuel sources such as jatropha that has previously been introduced in Indonesia, have their own problems with limited seed productivity resulting in production inefficiencies and land use competition for food purposes. Provision of non-edible plant sources of biofuel that do not pose significant threats to farmlands is therefore critical.
The seeds of Calophyllum inophyllum (common name: nyamplung) have long been used for biofuel; therefore it is one of the potential tree species for energy sources (Soeryawidjaja, 2005; Sopamena, 2007). The seeds can be harvested repeatedly from a nyamplung tree until the tree is 50 years old. In its natural habitat, nyamplung grows along the coast line which less interference with food production. Nyamplung has been grown in Indonesia as wind break along marginal coastal areas and planted on unproductive lands for 50 years. Nyamplung seed production reachs 40-150 $\mathrm{kg} /$ tree/year corresponding to 20 ton/ha/year exceeding the seed production of other species for similar pupose such as jatropha (5 ton/ha/ year) and oil palm (6 ton/ha/year) (Bustomi et al., 2008).

Commercially, biofuel of nyamplung has been produced intensively by Jarak Lestari Cooperation in Cilacap (Java) and Energy Self-Sufficient Villages (Desa Mandiri Energi) in Banyuwangi, Purworejo, Kebumen, Ujung Kulon (Java) and Selayar (South Sulawesi) (Dephut, 2008; ESDM, 2006, 2007, 2008). Biofuel from nyamplung can substitute fossil fuels. The foremost obstacle for nyamplungbased bioenergy to production is the limitation of nyamplung seeds as raw materials. Reliance on raw materials from unselected natural or planted stands and the lack of improved nyamplung seeds have been suggested as the causes of inconsistency in nyamplung oil production and quality. Strategic breeding is one possible solution to enhance nyamplung oil quality (Leksono and Widyatmoko, 2010). 
It started with identification of initial stand potential and land properties within and between 6 nyamplung population from Java (Leksono et al., 2010) and from 6 population outside Java (Leksono, 2011).

The high level of phenotypic variation among populations led to the necessity to undertake studies on examining oil potential and charactersistic within each population and among nyamplung population in Indonesia. This information is essential for assessing the potential of nyamplung forest plantations in Indonesia to support biofuel program and the benefits that would results from genetic improvement. With regard to those purposes research here was conducted to analyze biofuel characteristics of nyamplung from each population and to provide information on variation in biofuel production and quality, including content of crude oil, refined oil and biodiesel.

\section{MATERIAL AND METHOD}

\section{A. Time and Location}

This study comprising collecting genetic materials (seeds) and analyses of nyamplung biofuel (Crude Oil, Refined Oil, and Biodiesel), was conducted during 2009-2012. Materials were collected from 12 nyamplung populations (provenances and land races) in Indonesia describe below. The pressing process and analyses of nyamplung biofuel were carried out in several laboratories:

1. Energy and Agro Electrification Laboratory, Faculty of Agricultural Technology, Bogor Agricultural University (IPB) in Bogor, using Vertical Hot Press (VHP) to produce crude oil and refined oil and physicalchemical analyses of crude oil of six populations from Java and two populations from Sumenep (Madura) and Selayar (South Sulawesi).

2. Bioenergy Laboratory, CV. Cahaya Khatulistiwa in Yogyakarta, using Screw Press Expeller (SPE) to produce crude oil, refined oil and biodiesel of seven populations from seven islands (six populations from outside Java and one population from Gunug Kidul (Jogjakarta)).

3. Oil physical character and oil chemical character Laboratories, Research and Development Center for Oil and Gas Technology "LEMIGAS", Ministry of Energy and Mineral Resources, Jakarta, to analyze physical-chemical properties of nyamplung biodiesel from seven populations of seven islands in Gunung Kidul (Jogjakarta), Pariaman (West Sumatra), Ketapang (West Kalimantan), Sumenep (Madura), Dompu (West Nusa Tenggara), Selayar (South Sulawesi), Yapen (Papua).

\section{B. Material and Methods}

Biofuel analyses was undertaken using seeds from 12 nyamplung populations in Indonesia represented by six populations (natural and plantations) in Java (Table 1) and 6 populations outside Java (Tabel 2). The fruits were collected from trees and under the trees at each population. Materials for biofuel analyses included lint, $\mathrm{H}_{3} \mathrm{PO}_{4}$, aquadest, methanol, $\mathrm{NaOH}, \mathrm{H}_{2} \mathrm{SO}_{4}$. Tools and equipments used for carrying out the researche included analytical balance, wooden hammer, fruit and seed cracker, grinder, vertical hot press, screw press expeller, funnel, separating funnel, erlenmeyer, measuring glass, heater and magnetic stirrer.

\section{Method}

1. Preparation of genetic materials (seeds)

Nyamplung fruits were collected and crushed to separate fruit flesh and shell, followed by further breakage of the shell to release the seeds. Seed samples were dried under the sun for three days to obtain dry seed weight with water content of $8-12 \%$. The fruit and seed sizes of nyamplung and the percentage of seed weight (wet and dry conditions) against fruit weight (dry condition) are presented in Table 3 and Table 4. 
Table 1. Environmental conditions of six nyamplung populations in Java

\begin{tabular}{|c|c|c|c|c|c|c|c|}
\hline No & $\begin{array}{l}\text { Nyamplung } \\
\text { population }\end{array}$ & $\begin{array}{l}\text { Geographical } \\
\text { positions }\end{array}$ & Population type & $\begin{array}{l}\text { Altitude } \\
\text { (masl) }\end{array}$ & $\begin{array}{l}\text { Soil } \\
\text { texture }\end{array}$ & $\begin{array}{l}\text { Temp. } \\
\left({ }^{\circ} \mathrm{C}\right)\end{array}$ & $\begin{array}{l}\text { Rainfall } \\
(\mathrm{mm} / \mathrm{yr})\end{array}$ \\
\hline 1. & $\begin{array}{l}\text { Banyuwangi } \\
\text { (East Java) }\end{array}$ & $\begin{array}{l}08^{\circ} 26^{\prime} 45^{\prime \prime} \quad \text { South } \\
114^{\circ} 20^{\prime} 16^{\prime \prime} \text { East }\end{array}$ & $\begin{array}{l}\text { Natural forest, } \\
\text { along the coast }\end{array}$ & 0 & Sandy & $23-32$ & 1400 \\
\hline 2. & $\begin{array}{l}\text { Gunung Kidul } \\
\text { (Jogjakarta) }\end{array}$ & $\begin{array}{l}07^{\circ} 53 \text { '25" South } \\
110^{\circ} 32^{\prime} 55^{\prime \prime} \text { East }\end{array}$ & $\begin{array}{l}\text { Plantation, hilly } \\
\text { limestone }\end{array}$ & 150 & Clayish & $21-32$ & 1800 \\
\hline 3. & $\begin{array}{l}\text { Purworejo } \\
\text { (Central Java) }\end{array}$ & $\begin{array}{l}07^{\circ} 50^{\prime} 57^{\prime \prime} \text { South } \\
109^{\circ} 53^{\prime} 42^{\prime \prime} \text { East }\end{array}$ & $\begin{array}{l}\text { Plantation, along } \\
\text { the coast }\end{array}$ & 0 & Sandy & $23-32$ & 1400 \\
\hline 4. & $\begin{array}{l}\text { Cilacap } \\
\text { (Central Java) }\end{array}$ & $\begin{array}{l}07^{\circ} 41^{\prime} 20^{\prime \prime} \text { South } \\
109^{\circ} 8 ’ 35^{\prime} \text { "East }\end{array}$ & $\begin{array}{l}\text { Natural forest, } \\
\text { along the coast }\end{array}$ & $5-8$ & $\begin{array}{l}\text { Loamy } \\
\text { clay }\end{array}$ & $23-32$ & 1000 \\
\hline 5. & $\begin{array}{l}\text { Ciamis } \\
\text { (West Java) }\end{array}$ & $\begin{array}{l}07^{\circ} 45^{\prime} 0.23^{\prime \prime} \text { South } \\
108^{\circ} 30^{\prime} 8.29^{\prime \prime} \text { East }\end{array}$ & $\begin{array}{l}\text { Natural forest, } \\
\text { along the coast }\end{array}$ & $2-5$ & Sandy & $23-32$ & 3000 \\
\hline 6. & $\begin{array}{l}\text { Pandeglang } \\
\text { (Banten) }\end{array}$ & $\begin{array}{l}06^{\circ} 08^{\prime} 0^{\prime \prime} \text { South } \\
105^{\circ} 50^{\prime} 0^{\prime \prime} \text { East }\end{array}$ & $\begin{array}{l}\text { Natural forest, } \\
\text { along the coast }\end{array}$ & 0 & $\begin{array}{l}\text { Sandy } \\
\text { clay }\end{array}$ & $19-32$ & 3100 \\
\hline
\end{tabular}

Source : Leksono et al. (2010)

Table 2. Environmental conditions of six nyamplung populations outside Java

\begin{tabular}{|c|c|c|c|c|c|c|c|}
\hline No & $\begin{array}{l}\text { Nyamplung } \\
\text { population }\end{array}$ & $\begin{array}{l}\text { Geographical } \\
\text { positions }\end{array}$ & $\begin{array}{l}\text { Population } \\
\text { type }\end{array}$ & $\begin{array}{l}\text { Altitude } \\
\text { (masl) }\end{array}$ & $\begin{array}{l}\text { Soil } \\
\text { texture }\end{array}$ & $\begin{array}{l}\text { Temp. } \\
\left({ }^{\circ} \mathrm{C}\right)\end{array}$ & $\begin{array}{l}\text { Rainfall } \\
(\mathrm{mm} / \mathrm{yr})\end{array}$ \\
\hline 1. & $\begin{array}{l}\text { Pariaman } \\
\text { (West Sumatra) }\end{array}$ & $\begin{array}{l}0^{\circ} 35^{\prime} 39^{\prime \prime} \text { 'South } \\
100^{\circ} 06^{\prime} 09^{\prime \prime} \text { East }\end{array}$ & $\begin{array}{l}\text { Natural forest, } \\
\text { along the coast }\end{array}$ & 0 & Sandy & $23-32$ & 2000 \\
\hline 2. & $\begin{array}{l}\text { Ketapang } \\
\text { (West Kalimantan) }\end{array}$ & $\begin{array}{l}01^{\circ} 12^{\prime} 52,20^{\prime \prime} \text { South } \\
109^{\circ} 55^{\prime} 50.52^{\prime \prime} \text { East }\end{array}$ & $\begin{array}{l}\text { Natural forest, } \\
\text { along the coast }\end{array}$ & $0-15$ & Sandy & $25-30$ & 2000 \\
\hline 3. & $\begin{array}{l}\text { Sumenep } \\
\text { (Madura) }\end{array}$ & $\begin{array}{l}07^{\circ} 04^{\prime} 31.6^{\prime \prime} \text { South } \\
113^{\circ} 49^{\prime} 50.1^{\prime \prime} \text { East }\end{array}$ & $\begin{array}{l}\text { Natural forest, } \\
\text { along the coast }\end{array}$ & $2-3$ & Sandy & $26-29$ & 900 \\
\hline 4. & $\begin{array}{l}\text { Dompu } \\
\text { (West N.Tenggara) }\end{array}$ & $\begin{array}{l}08^{\circ} 17.18^{\prime} 0.2^{\prime \prime} \text { South } \\
117^{\circ} 59^{\prime} 54.2^{\prime \prime} \text { East }\end{array}$ & $\begin{array}{l}\text { Natural forest, } \\
\text { along the coast }\end{array}$ & 0 & Sandy & $20-32$ & 500 \\
\hline 5. & $\begin{array}{l}\text { Selayar } \\
\text { (South Sulawesi) }\end{array}$ & $\begin{array}{l}06^{\circ} 09^{\prime} 8.2^{\prime \prime} \text { South } \\
120^{\circ} 30^{\prime} 51.7 \text { " East }\end{array}$ & $\begin{array}{l}\text { Natural forest, } \\
\text { hilly areas }\end{array}$ & $9-35$ & Clayish & $21-34$ & 1700 \\
\hline 6. & $\begin{array}{l}\text { Yapen } \\
\text { (Papua) }\end{array}$ & $\begin{array}{l}01^{\circ} 56^{\prime} 04.1^{\prime \prime} \text { South } \\
136^{\circ} 21^{\prime} 49.4^{\prime \prime} \text { East }\end{array}$ & $\begin{array}{l}\text { Natural forest, } \\
\text { along the coast }\end{array}$ & 0 & Sandy & $24-30$ & 1500 \\
\hline
\end{tabular}

Source : Leksono et al. (2011)

\section{Pressing seeds}

Currently, there are two equipments used for extracting biofuel from nyamplung seeds; hydraulic press machine and screw press machine (Sudradjad and Hendra, 2012). Nyamplung biofuels from Java populations were assessed using vertical hot press, a hydraulic press technology available at that time. Nyamplung seeds of six populations from Java and three populations from outside Java were collected for pressing using Vertical Hot Press (VHP) method and nyamplung seeds of six populations from Java with one additional population from Gunung Kidul (Jogjakarta) to represent Java populations were collected for pressing using Screw Press Expeller (SPE) method.

\section{Degumming process}

Degumming is the process of separating oil and gum from Crude Calophyllum Oil (CCO) produce from both methods (VHP and SPE). The method was conducted by diluting with $1 \%$ phosphoric acid $\left(\mathrm{H}_{3} \mathrm{PO}_{4}\right)$ of the $\mathrm{CCO}$ volume 
Table 3. Average fruit and seed sizes of nyamplung from six Java populations

\begin{tabular}{lcccccc}
\hline \multirow{2}{*}{$\begin{array}{c}\text { Nyamplung } \\
\text { Population }\end{array}$} & $\begin{array}{c}\text { Weight } \\
(\text { gram })\end{array}$ & $\begin{array}{c}\text { Length } \\
(\mathrm{cm})\end{array}$ & $\begin{array}{c}\text { Diameter } \\
(\mathrm{cm})\end{array}$ & $\begin{array}{c}\text { Weight } \\
(\mathrm{gram})\end{array}$ & $\begin{array}{c}\text { Length } \\
(\mathrm{cm})\end{array}$ & $\begin{array}{c}\text { Diameter } \\
(\mathrm{cm})\end{array}$ \\
\hline Banyuwangi (East Java) & 10.0 & 3.0 & 2.8 & 1.4 & 1.1 & 1.1 \\
Gunung Kidul (Jogjakarta) & 7.7 & 2.9 & 2.5 & 1.9 & 2.1 & 1.5 \\
Purworejo (Central Java) & 7.1 & 2.7 & 2.5 & 1.7 & 1.9 & 1.5 \\
Cilacap (Central Java) & 11.1 & 3.0 & 2.8 & 1.8 & 2.2 & 1.5 \\
Ciamis (West Java) & 9.0 & 3.0 & 2.8 & 1.9 & 2.4 & 1.6 \\
Pandeglang (Banten) & 8.7 & 31 & 2.7 & 1.9 & 2.2 & 1.6 \\
\hline
\end{tabular}

Source : Leksono et al. (2012)

Table 3. The weight of fruit weight, seed shell, wet seed and dry seed of seven nyamplung populations from 7 islands in Indonesia

\begin{tabular}{llccccccc}
\hline No & \multicolumn{1}{c}{$\begin{array}{c}\text { Nyamplung } \\
\text { Populations }\end{array}$} & $\begin{array}{c}\text { FW } \\
(\mathrm{Kg})\end{array}$ & $\begin{array}{c}\text { SS } \\
(\mathrm{Kg})\end{array}$ & $\begin{array}{c}\mathrm{SS} / \mathrm{FW} \\
(\%)\end{array}$ & $\begin{array}{c}\text { WS } \\
(\mathrm{Kg})\end{array}$ & $\begin{array}{c}\text { WS/FW } \\
(\%)\end{array}$ & $\begin{array}{c}\text { DS } \\
(\mathrm{Kg})\end{array}$ & $\begin{array}{c}\text { DS/ } \\
\text { FW } \\
(\%)\end{array}$ \\
\hline 1. & Gunung Kidul (Jogjakarta) & 20 & 11.5 & 57.5 & 8 & 40 & 7.3 & 36.5 \\
2. & Sumenep (Madura) & 20 & 11.0 & 55.0 & 7 & 35 & 6.0 & 30 \\
3. & Selayar (South Sulawesi) & 20 & 12.0 & 60.0 & 8 & 40 & 6.0 & 30 \\
4. & Padang (West Sumatra) & 20 & 11.0 & 55.0 & 7 & 35 & 6.0 & 30 \\
5. & Ketapang (West Kalimantan) & 20 & 12.0 & 60.0 & 7 & 35 & 6.0 & 30 \\
6. & Dompu (NTB) & 20 & 11.0 & 55.0 & 7 & 35 & 6.0 & 30 \\
7. & Yapen (Papua) & 20 & 11.5 & 57.5 & 7 & 35 & 6.0 & 30 \\
\hline
\end{tabular}

Key: $\mathrm{FW}=$ fruit weight, $\mathrm{SS}=$ seed shell, $\mathrm{WS}=$ wet seed, $\mathrm{DS}=$ dry seed

into $\mathrm{CCO}$, followed by heating up to $60^{\circ} \mathrm{C}$ and 30 minute stirring. Green CCO will turn into brownish or yellowish color depending on the characters of the processed nyamplung seeds. After heating, CCO was left for 4-6 hours, so that the gum would be separated at the bottom while the degumming oil would float on the top. The oil was taken as refined oil/refined crude calophyllum oil (RCCO).

\section{Esterification-Transesterification-Biodiesel process}

Esterification is a reaction process of changing Free Fatty Acid (FFA) into Fatty Acid Methyl Eter (FAME) compounds, a generic name of biodiesel. In this esterification process, oil from degumming (Refined Crude Calophyllum Oil) process was reacted with $20 \%$ methanol and $2 \% \mathrm{H}_{2} \mathrm{SO}_{4}$ catalyst of the RCCO volume. The sulfuric acid $\left(\mathrm{H}_{2} \mathrm{SO}_{4}\right)$ was mixed into methanol and stirred until it was perfectly dissolved before pouring it into RCCO. It was then heated up to $60-65^{\circ} \mathrm{C}$ with 2 hour stirring. In this esterification process, the oil will release its acid grease that will stay at the bottom separated from ester oil at the top

Transesterification is a reaction to change triglyceride into FAME compounds. In this process, ester oil was reacted to $20 \%$ methanol and $1 \% \mathrm{NaOH}$ catalyst of the ester oil volume. $\mathrm{NaOH}$ was mixed into the methanol and it needed to be perfectly dissolved before pouring it into ester oil. It was then heated up to $60-65^{\circ} \mathrm{C}$ for 2 hours. Transesterification content was set to separate oil (crude biodiesel) and glycerol.

In producing biodiesel, crude biodiesel (transesterification content) needs to be washed and dried. Washing was carried out by mixing $30 \%$ warm water of the crude biodiesel 
at $50^{\circ} \mathrm{C}$ into crude biodiesel, with 3 minute stirring. It was then set for 1 hour to separate water, at the bottom and wet biodiesel, at the top. Washing was conducted until the water was clear. Wet biodiesel with high moisture content looks blurry, therefore in order to produce clear transparent biodiesel, the solution was heated up to $90-100^{\circ} \mathrm{C}$ to evaporate the water content.

Analyses of physical and chemical nyamplung biodiesel was undertaken to assess 18 biodiesel properties as prerequisites for qualified biodiesel. Analyses were carried out by using method of esther alkil biodiesel quality testing according to SNI 04-7182-2006 for biodiesel. Analyses were conducted for each biodiesel from seven nyamplung populations from seven islands in Indonesia.

\section{Determination of Biofuel Content}

Biofuel analyses of nyamplung was carried out to examine variation in the potential of biofuel from 6 nyamplung populations in Java and 7 island populations in Indonesia (including 1 population from Jawa). The former was conducted to assess the content of crude calophyllum oil (CCO) and refined crude calophyllum oil (RCCO), while the latter was for the CCO, RCCO, and biodiesel. Formula used to calculate these three parameters is as follow:

$$
\text { Biofuel content }=\frac{\text { Weight of biofuel extraction }}{\text { Seed weight }} \times 100 \%
$$

Where:

Biofuel content $=$ content of $\mathrm{CCO} / \mathrm{RCCO} /$ Biodiesel $(\%)$; Weight of biofuel extraction $=$ weight of $\mathrm{CCO} /$ RCCO/Biodiesel (kg); Seed weight $=$ weight of dry nyamplung seeds $(\mathrm{kg})$

\section{RESULT AND DISCUSSION}

\section{A. Variation in Biofuel Potential of Nyamplung Populations from Java}

The nyamplung biofuel content (CCO) of Javanese populations is as presented in Table 5 . Variation between populations is evident in the six physical and chemical properties presented in Table 5, although it is not significant. The characteristic of nyamplung oil are similar among Java populations which is dark green, viscous and with strong aroma (Leksono and Putri, 2012). The physical performance of CCO might be influenced by shell residue and other chemicals such as alkaloid, phosphatide, carotenoid, chlorophyl and other dark constituents (Sudrajad and Hendra, 2012). Therefore degumming CCO to produce RCCO is essential, before processing into biokerosene and biodiesel (Table 5).

The results of pressing procedure and biofuel analyses (Table 5) demonstrates that the average biofuel contents from dry weight seed of the 6 Java population is $42.40 \%$ (CCO) and $41.04 \%$ (RCCO) and it varies among populations with $10 \%$ on the range of $37.02 \%$ - 48.57\% (CCO) and 36.49 - 47.60\% (RCCO). $\mathrm{CCO}$ contents processed by vertical hot press are higher in comparison to jatropha (25 - 40\%),

Table 5. Calophyllum crude oil (CCO) and refined calophyllum crude oil (RCCO) contents of Nyamplung from 6 Java populations

\begin{tabular}{|c|c|c|c|c|c|c|c|}
\hline No & Nyamplung Populations & $\begin{array}{c}\text { Dry seeds } \\
\quad(\mathrm{Kg})\end{array}$ & $\begin{array}{c}\text { Residual } \\
\text { waste }(\mathrm{Kg})\end{array}$ & $\mathrm{CCO}(\mathrm{Kg})$ & $\begin{array}{c}\mathrm{CCO} \\
(\%)\end{array}$ & $\begin{array}{c}\text { RCCO } \\
(\mathrm{Kg})\end{array}$ & $\begin{array}{c}\text { RCCO } \\
(\%)\end{array}$ \\
\hline 1. & Banyuwangi (East Java) & 2.09 & 1.20 & 0.89 & 42.58 & 0.87 & 41.63 \\
\hline 2. & Gunung Kidul (Jogjakarta) & 2.10 & 1.08 & 1.02 & 48.57 & 1.00 & 47.60 \\
\hline 3. & Purworejo (Central Java) & 1.90 & 1.04 & 0.87 & 45.79 & 0.84 & 43.65 \\
\hline 4. & Cilacap (Central Java) & 2.10 & 1.25 & 0.85 & 40.48 & 0.78 & 37.24 \\
\hline 5. & Ciamis (West Java) & 2.00 & 1.20 & 0.80 & 40.00 & 0.79 & 39.60 \\
\hline 6. & Pandeglang (Banten) & 1.81 & 1.16 & 0.67 & 37.02 & 0.66 & 36.49 \\
\hline \multicolumn{2}{|c|}{ Average } & & & & 42.40 & & 41.04 \\
\hline
\end{tabular}


sterculia $(25-40 \%)$ and schleichera $(27 \%)$ (Heyne, 1987; Sudrajad et al., 2010a; Sudrajad et al., 2010b; Hasnam, 2011; Raja et al., 2011). These findings show that nyamplung seeds are very promising as an alternative raw material for biofuel. The highest CCO and RCCO contents (Table 5) were obtained from the population of Gunung Kidul with the values of $48.57 \%$ and $47.60 \%$, respectively, while the lowest values were obtained from Pandeglang (Banten) populations with $37.02 \%$ and $36.49 \%$, respectively.

In general, biofuel contents of the 6 Java populations (CCO and RCCO) illustrate the variations among Java populations. This means that differences of genetic factors associated with population (intra-spesific variation) will affect the final production (Zobel and Talbert 1984). Variation of fruit and seed sizes of the same 6 populations from Java, are also evident (Table 5). This implies that differences of genetic factors from each nyamplung population will affect the physical characters of fruits and seeds that will be produced. These results indicate the lack of relationship between biggest fruit weight classification and their seed weight classification as well as there was no relationship between smallest fruit weight classification and their seeds (Leksono and Putri, 2012). There have been no reports on relationship between seed size and biofuel content. Seed size may not be the only factor influencing the contents, and variation of gum content among nyamplung populations may also affect biofuel contents.

\section{B. Variations in Biofuel Potential of Seven Nyamplung Populations from Seven Islands in Indonesia}

Seed pressing process to examine the potential of CCO from 7 islands in Indonesia was carried out by using 2 types of equipment: VHP for 3 populations and SPE for 7 populations. The biofuel potential (CCO, RCCO and biodiesel) of 7 populations from 7 islands in Indonesia are shown in Table 6.

Results show that use of SPE produce 5 - 13\% higher CCO contents (in the range of $50-53 \%)$ than by use of VHP $(40-45 \%)$. Table 6 shows that by use of SPE has also produced much higher nyamplung biofuel contents when compared to extraction from jatropha $(25-50 \%)$, sterculia $(25-40 \%)$ and schleichera (27\%) (Heyne 1987, Sudradjad and Setiawan 2005; Sudrajad et al., 2010a, Sudrajad et al., 2010b, Hasnam 2011, Raja et al., 2011).

Table 6. Contents of CCO, RCCO, and nyamplung biodiesel from dry seed weight of nyamplung collected from 7 islands in Indonesia

\begin{tabular}{llccccc}
\hline No & \multicolumn{1}{c}{$\begin{array}{c}\text { Nyamplung } \\
\text { Populations }\end{array}$} & $\begin{array}{c}\text { Dry seed } \\
(\mathrm{Kg})\end{array}$ & $\begin{array}{c}\text { CCO } \\
(\%)\end{array}$ & $\begin{array}{c}\text { RCCO } \\
(\%)\end{array}$ & $\begin{array}{c}\text { Biodiesel } \\
(\%)\end{array}$ & $\begin{array}{c}\text { Equipments } \\
\text { used }\end{array}$ \\
\hline 1. & Gunung Kidul (Jogjakarta) & 4.8 & 43.75 & 38.06 & - & VHP \\
2. & Sumenep (Madura) & 4.8 & 40.63 & 34.13 & - & VHP \\
3. & Selayar (South Sulawesi) & 4.8 & 45.63 & 40.15 & - & VHP \\
4. & Gunung Kidul (Jogjakarta) & 7.3 & 50.00 & 46.85 & 28.95 & SPE \\
5. & Sumenep (Madura) & 6.0 & 53.17 & 44.67 & 21.00 & SPE \\
6. & Selayar (South Sulawesi) & 6.0 & 50.17 & 40.67 & 30.00 & SPE \\
7. & Pariaman (West Sumatera) & 6.0 & 50.17 & 36.00 & 17.00 & SPE \\
8. & Ketapang (West Kalimantan)* & 6.0 & 27.50 & 24.50 & 18.70 & SPE \\
9. & Dompu (NTB) & 6.0 & 58.33 & 53.00 & 33.83 & SPE \\
10. & Yapen (Papua)* & 6.0 & 37.67 & 22.83 & 16.00 & SPE \\
\hline
\end{tabular}

Note: $\left.{ }^{*}\right)=$ technical problems occurrred during the pressing process by using SPE, VHP $=$ Vertical Hot Press, SPE $=$ Screw Press Expeller 
This has encouraged the use of nyamplung as prospective alternative of raw material for biofuel production. Improvement of the processing for biofuel production is in progress. It is expected that the range of biofuel content produced in this study can be enhanced using more effective and efficient process of oil analyses.

Table 3 and Table 6 show different results in case of nyamplung from Gunung Kidul population. This may be affected by the different time of sample collections, where Table 3 shows fruit collection in 2010 and Table 6 shows collection in 2011. This information also describes the differences in biofuel contents even from the same population when seeds are collected at different time because the seeds are collected from open pollinated crossings. This also reveals that biofuel contents may vary depending on population origin, time of collection, age of tree and processing equipment (Sudradjad and Setiawan 2005, Sudrajad et al., 2010a, Sudrajad et al., 2010b, Hasnam 2011).

The highest contents of CCO, RCCO and biodiesel of the 7 populations from the 7 islands in Indonesia (Table 6) are obtained from the Dompu (NTB) populations with the values of $58.3 \%, 53.0 \%$ and $33.8 \%$ respectively, compared with biofuel contents from other populations with the values of $50-53 \%, 36$ 44\% and $17-30 \%$, respectively. Examination will be carried out later after obtaining seeds from the same populations. High variations of biofuel content between the 7 islands sampled Suggest that improvement program through selection among nyamplung provenances will be very effective and thus should be conducted.

Biodiesel contents of the 7 islands were then analyzed further for physical-chemical biodiesel properties based on SNI 04-7182-

Table 7. Physical-chemical properties of nyamplung biodiesel in comparison with SNI 04-7182 2006 standard

\begin{tabular}{|c|c|c|c|c|c|}
\hline No. & Properties & Unit & $\begin{array}{l}\text { Testing } \\
\text { Methode }\end{array}$ & $\begin{array}{c}\text { Spec. } \\
\text { Biodiesel } \\
\end{array}$ & $\begin{array}{c}\text { Nyamplung } \\
\text { Biodiesel }\end{array}$ \\
\hline 1. & Density at $40^{\circ} \mathrm{C}$ & $\mathrm{kg} / \mathrm{m}^{3}$ & ASTM D.1298 & $850-890$ & $895-903$ \\
\hline 2. & Kinematic viscosity at $40^{\circ} \mathrm{C}$ & cSt & ASTM D.445 & $2.3-6.0$ & $5.7-6.5$ \\
\hline 3. & Flash point PMCC & ${ }^{\circ} \mathrm{C}$ & ASTM D.93 & Min. 100 & $126-173$ \\
\hline 4. & Cetane index & - & ASTM D.613 & Min. 51 & $59-72$ \\
\hline 5. & Cloud point & ${ }^{\circ} \mathrm{C}$ & ASTM D.2500 & Max. 18 & $11-16$ \\
\hline 6. & Sediment and water content & $\%$ Vol. & ASTM D.1796 & Max. 0.05 & 0 \\
\hline 7. & Copperstrip corrosion at $3 / 50^{\circ} \mathrm{C}$ & No. ASTM & ASTM D.130 & Max.no 3 & $1 a-1 b$ \\
\hline 8. & Micro Carbon Residual (MCR) & $\% \mathrm{wt}$ & ASTM D.4530 & Max.0.05 & $0.6-0.9$ \\
\hline 9. & Sulphate Ash & $\%$ wt & ASTM D.874 & Max.0.02 & $0.002-0.01$ \\
\hline 10. & Destilation at $90 \% \mathrm{Vol}$ & ${ }^{\circ} \mathrm{C}$ & ASTM D.1160 & Max. 360 & $365-369$ \\
\hline 11. & Sulphur content & $\mathrm{mg} / \mathrm{kg}$ & ASTM D.4294 & Max. 100 & $9-19$ \\
\hline 12. & Phosphor content & $\mathrm{mg} / \mathrm{kg}$ & AOCS Ca $12-55$ & Max. 10 & $0.19-0.33$ \\
\hline 13. & Acid value & $\mathrm{Mg} \mathrm{KOH} / \mathrm{g}$ & ASTM D.974 & Max. 0.8 & $0.05-0.08$ \\
\hline 14. & Free Glycerol & $\% \mathrm{wt}$ & AOCS Ca 14-56 & Max. 0.02 & $0.01-0.04$ \\
\hline 15. & Total Glycerol & $\%$ wt & AOCS Ca 14-56 & Max.0.24 & $0.14-0.24$ \\
\hline 16. & Esther alkali & $\%$ wt & Calculation & Min. 96.5 & $98-99$ \\
\hline 17. & Iodine value & $\% \mathrm{wt}$ & AOCS Cd 1-25 & Max. 115 & $59-96$ \\
\hline 18. & Halphen test & - & AOCS Cb 1-25 & Negative & Negative \\
\hline
\end{tabular}


2006 standard (Badan Standardisasi Nasional, 2006) as presented in Table 7.

Several physical-chemical properties of nyamplung biodiesel (Tabel 7) fulfill the requirements of SNI 04-7182-2006 standard, These are: flash point, cetane index, cloud point, sediment and water content, copper strip corrosionat, sulphat ash, sulphur, phosphor, acid value, total glycerol, esther alkali, iodine value and halphen test. Several parameters do not meet the standard. These are: specific gravity, kinematic viscousity, micro carbon residual, destilation and free glycerol.

In general, the biodiesel quality does not comply with the Indonesian Standard (SNI) for biodiesel, indicates the importance of improvement in the processing of $\mathrm{CCO}$ into biodiesel. From those biodiesel properties, cetane value determines the temperature of the burning point and easeness for the machine to start; acid value verifies the corrosive level of biodiesel to the machine ignition point determines the safety for transporting biodiesel due to its sensitivity to inflammation; esther alkali indicates the percentage of fatty acid converted into methyl esther; iodine value denotes the number of double bond in free fatty acid; viscosity implies biodiesel thickness that determines smoothness of the flowing in the machinery; fogging point relates to the easeness for biodiesel to frost. Other parameters are related to emission and pollution (Sudrajad and
Hendra, 2012).

\section{Genetic Diversity of Nyamplung}

Understanding the genetic diversity of nyamplung populations is critical for genetic improvement. DNA analyses using RAPD was used to assesses genetic diversity in the sample populations. The results of this analysis suggest that nyamplung population in Java could be divided into two clusters at $99 \%$ significance level, and the 7 populations from the 7 islands in Indonesia could also be devided into two clusters at the $89 \%$ significance level (Figure 1 and Figure 2 - Nurtjahjaningsih, 2012).

\section{CONCLUSION}

Oil content of nyamplung biofuel (CCO and $\mathrm{RCCO}$ ) from 6 Java populations, processed using vertical hot press, range $37.02 \%$ $48.57 \%$ and $36.49-47.60 \%$ respectively. The highest contents are produced by Gunung Kidul (Jogjakarta) population with 48.57\% and $47.60 \%$, and the lowest by Pandeglang (Banten) population with $37.02 \%$ and $36.49 \%$ respectively.

Oil content of nyamplung biofuel from the 7 populations of the 7 islands in Indonesia, processed by using vertical hot press, range 40.63 - 45.63\% (CCO) and 38.06 - 40.15\% (RCCO), and using screw press expeller, from 50.17 - 58.33\% (CCO), 36 - 53\% (RCCO) and $17-33.83 \%$ (biodiesel). The highest content is

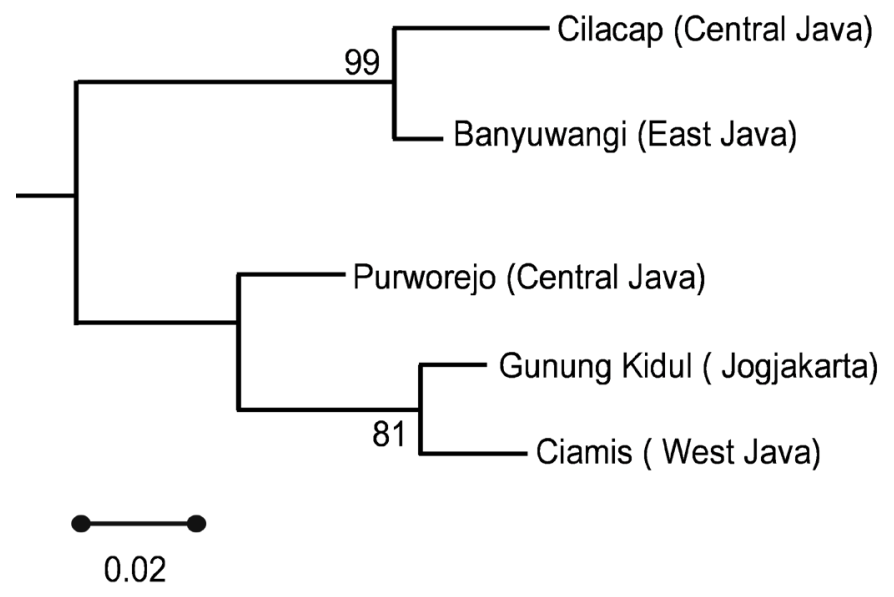

Figure 1. A dendrogram of nyamplung populations in Java 


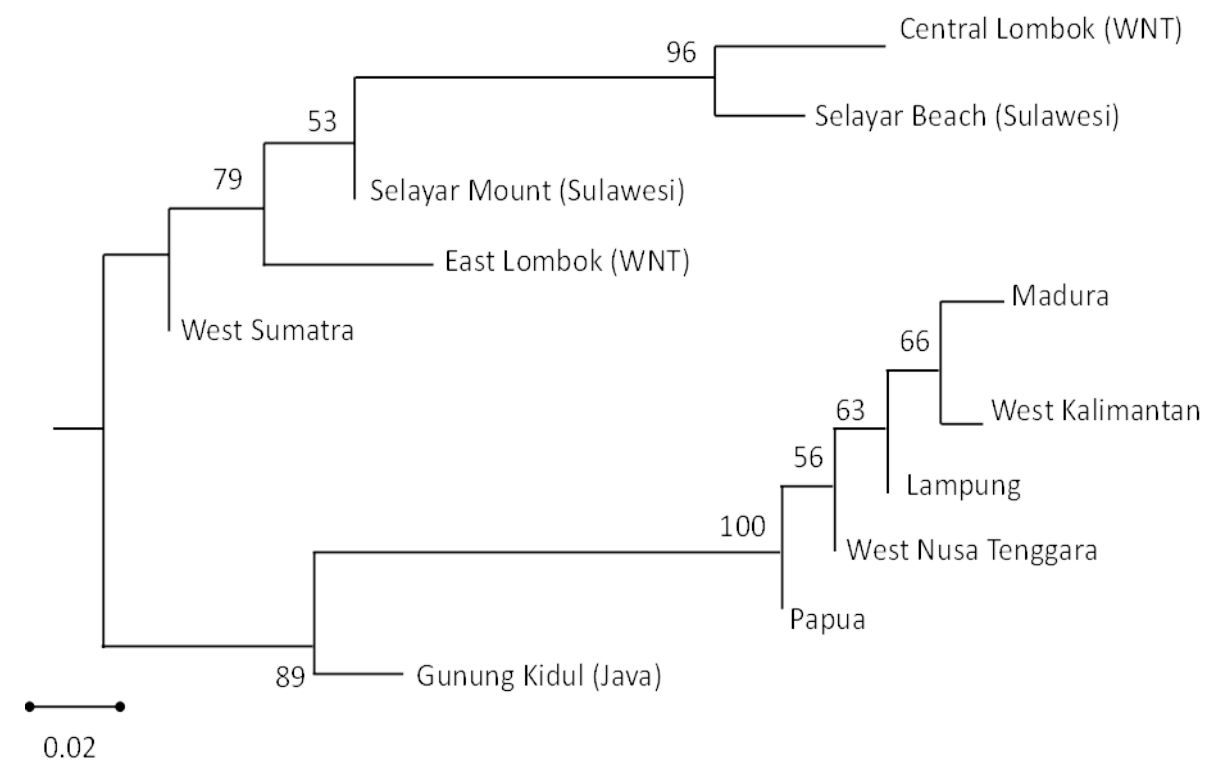

Figure 2. A dendrogram of nyamplung populations in Indonesia

produced by Dompu (NTB) population with $58.33 \%, 53 \%$ and $33.83 \%$ for CCO, RCCO and biodiesel, respectively.

Among 18 oil properties tested, 13 oil properties have met the Indonesian SNI 04-7182-2006 standard. CCO process of nyamplung biodiesel need to be enhanced in order to meet the standard.

A high variations of nyamplung biofuel content and high genetic diversity of 12 nyamplung populations in Indonesiaprovide promising potential for enhanching biofuel productivity through genetic improvement of nyamplung. Establishment of nyamplung populations with high biofuel potential outside its natural distribution require trials to evaluate their adaptive capability and the level of reproducing flower and fruit production.

\section{ACKNOWLEDGEMENT}

We are very grateful to Research Incentive Programs of the Directorat General of Higher Education, The Ministry of National Education (2009), and The Ministry of Research and Technology (2010 to 2012) that provided funding to support this research. Thanks are also conveyed to Energy and
Agro Electrification Laboratory, Bogor Agricultural University; Bioenergy Laboratory, CV. Cahaya Khatulistiwa, Yogyakarta; and Oil Physical Character and Oil Chemical Character Laboratories, LEMIGAS, Ministry of Energy and Mineral Resources, Jakarta for their very well collaboration.

\section{REFERENCES}

Badan Standardisasi Nasional. (2006). Biodiesel: SNI 04-7182-2006. Jakarta: Badan Standarisasi Nasional (BSN).

Bustomi, S., Rostiwati, T., Sudradjat, R., Leksono, B., Kosasih, A. S., Anggraeni, I., ... Rahman, E. (2008). Nyamplung (Calopbyllum inophyllum L) sumber energi biofuel yang potensial. Jakarta: Badan Penelitian and Pengembangan Kehutanan.

Departemen Kehutanan. (2008). Minyak Nyamplung (Calophyllum inophyllum L) dari Kroya. Majalab Kebutanan Indonesia, 9.

Direktorat Jenderal Listrik and Pemanfaatan Energi. (2008). Rencana strategis 2009-2014 program desa mandiri energi. Jakarta: Kementerian Energi dan Sumberdaya Mineral RI.

Direktorat Jenderal Listrik dan Pemanfaatan Energi. (2007). Pengembangan desa mandiri energi (DME). Jakarta: Kementerian Energi dan Sumberdaya Mineral RI. 
Hasnam. (2011). Prospek perbaikan genetik jarak pagar (Jatropha curcas L.). Perspektif, 10(2), 70-80.

Hayes, D. J., Ballentine, R., \& Mazurek, J. (2007). The promise of biofuels: A bome-grown approach to breaking America's Oil Addiction (Policy Report March 2007). Progressive Policy Institute.

Heyne, K. (1987). Tumbuhan Berguna Indonesia Jilid III (Diterjemabkan oleh : Badan Litbang Kehutanan). Jakarta: Yayasan Sarana Wanajaya.

Leksono, B. (2009). Breeding zones based on genotype-environment interaction in seedling seed orchards of Eucalyptus pellita in Indonesia. Journal of Forestry Research, 6(1), 74-84.

Leksono, B. (2011). Pemuliaan nyamplung (Calophyllum inophyllum) untuk baban baku biofuel: Keragaman produktivitas biokerosin nyamplung di Indonesia. Laporan Penelitian Program Insentif Ristek Program Insentif Terapan-Sumber Energi Baru dan Terbarukan TA 2011 (Unpublished).

Leksono, B., Kurinobu, S., \& Ide, Y. (2011). A breeding strategy for the tropical Eucalyptus: Findings and lessons acquired from the multi-generation tree breeding of Eucalyptus pellita in Indonesia ( $\mathrm{p}$. 120). Saarbrücken, Germany: LAP Lambert Academic Publishing GmbH \& Co.KG.

Leksono, B., Lisnawati, Y., Rahman, E., \& P., P. K. (2010). Potensi tegakan and karakteristik lahan enam populasi nyamplung (Calophyllum inophyllum) ras Jawa. In Prosiding workshop sintesa basil penelitian butan tanaman 2010. (pp. 397-408). Bogor: Pusat Litbang Peningkatan Produktivitas Hutan.

Leksono, B., \& Putri, K. P. (2012). Variasi ukuran buah - biji dan sifat fisiko - kimia minyak nyamplung (C. Inophyllum L.) dari enam populasi di Jawa. In Prosiding Seminar Nasional HHBK (pp. 321 - 334). Mataram: BPTHHBK Mataram.

Leksono, B., \& Widyatmoko, A. Y. P. B. C. (2010). Strategi pemuliaan nyamplung (Calophyllum inophyllum) untuk bahan baku biofuel. In Prosiding Seminar Nasional Sains and Teknologi III: Peran Strategis Sains and Teknologi dalam Mencapai Kemandirian Bangsa. Bandar Lampung 18-19 Oktober 2010. (pp. 125-137). Bandar Lampung: Universitas Lampung.

Nurtjahjaningsih, I. L. G. (2012). Studi keragaman genetik flora jenis prioritas menggunakan penanda DNA (Calophyllum inophyllum) Laporan Hasil Penelitian (tidak dipublikasikan). Yogyakarta.

Nurtjahjaningsih, I. L. G., Sulistyawati, P., Widyatmoko, A. Y. P. B. C., \& Rimbawanto, A. (2012). Karakter pembungaan and sistem perkawinan nyamplung (Calophyllum inophyllum) pada hutan tanaman di Watusipat, Gunung Kidul. Jurnal Pemuliaan Tanaman Hutan, 6(2), 67-78.

Nurtjahjaningsih, I. L. G., \& Widyatmoko, A. Y. P. B. C. (2011). Mating system of Calophyllum inophyllum across three different forest types. In Proceeding International Conference of Indonesia Forestry Researchers "Strengthening Forest Science and Technology for Better Forestry Development". Bogor 5-7 Desember 2011 (pp. 82-89). Jakarta: Forestry Research and Development Agency, Ministry of Forestry Indonesia.

Raja, S. A., Roninson, \& Robert, C. L. L. (2011). Biodiesel production from jatropha oil and its characterizations. Res. J. Chem. Sci., 1(1), 81-87.

Sekretariat Panitia Teknis Sumber Energi. (2006). Blueprint pengelolaan energi nasional 2006-2025: Sesuai Peraturan Presiden Nomor 5 Tahun 2006. Jakarta: Kementerian Energi dan Sumberdaya Mineral RI.

Soerjawidjaja, T. H. (2005). Potensi sumber daya hayati indonesia dalam menghasilkan bahan bakar hayati BBM. In Makalab Lokakarya "Pengembangan and Pemanfaatan Sumber Energi Alternatif Untuk Keberlanjutan Industri Perkebunan and Kesejabteraan Masyarakat" Hotel Horrison Bandung.

Sopamena, C. H. A. (2007). Hitaullo (Calophyllum inophyllum L.): Sumber Energi Bahan Bakar Nabati (BBN) and Tanaman Konservasi. Bandung: BAPINDO.

Sudrajat, R., \& Hendra, D. (2012). Pengolahan Biofuel Nyamplung and Pemanfaatan Hasil Lainnya Nyamplung: Nyamplung (Calophyllum inophyllum L) Sumber energi biofuel yang potensial (Ed. Revisi.). Jakarta: Badan Penelitian and Pengembangan Kehutanan.

Sudrajat, R., Pawoko, E., Hendra, D., \& Setiawan, D. (2010). Pembuatan biodiesel dari biji kesambi (Scbleichera oleosa L). Jurnal Penelitian Hasil Hutan, 28(4), 358-379.

Sudrajat, R., \& Setiawan, D. (2005). Biodiesel dari 
tanaman jarak pagar sebagai energi alternatif untuk pedesaan. In Seminar Hasil Litbang Hasil Hutan (pp. 207-219). Bogor: Pusat Litbang Hasil Hutan.

Sudrajat, R., Yogie, S., Hendra, D., \& Setiawan, D. (2010). Pembuatan biodiesel kepuh dengan proses transesterifikasi. Jurnal Penelitian Hasil Hutan, 28(2), 145-155.

Zobel, B. J., \& Talbert, J. T. (1984). Applied forest tree improvement. New York, USA: John Wiley \& Sons Inc. 